\title{
SHORT COMMUNICATION The NF-kB subunit c-Rel regulates Bach2 tumour suppressor expression in B-cell lymphoma
}

\author{
JE Hunter ${ }^{1}$, JA Butterworth ${ }^{1}$, B Zhao ${ }^{2}$, H Sellier ${ }^{1}, \mathrm{KJ}_{\text {Campbell }}^{3}$, HD Thomas ${ }^{4}, \mathrm{CM}_{\text {Bacon }}^{4}$, SJ Cockell ${ }^{5}$, BE Gewurz ${ }^{2}$ and ND Perkins ${ }^{1}$
}

The REL gene, encoding the NF-KB subunit c-Rel, is frequently amplified in B-cell lymphoma and functions as a tumour-promoting transcription factor. Here we report the surprising result that $c-r e l-/-$ mice display significantly earlier lymphomagenesis in the c-Myc driven, E $\mu$-Myc model of B-cell lymphoma. c-Rel loss also led to earlier onset of disease in a separate TCL1-Tg-driven lymphoma model. Tumour reimplantation experiments indicated that this is an effect intrinsic to the E $\mu$-Myc lymphoma cells but, counterintuitively, c-rel-/- E $\mu$-Myc lymphoma cells were more sensitive to apoptotic stimuli. To learn more about why loss of c-Rel led to earlier onset of disease, microarray gene expression analysis was performed on B cells from 4-week-old, wild-type and c-rel-/E $\mu$-Myc mice. Extensive changes in gene expression were not seen at this age, but among those transcripts significantly downregulated by the loss of c-Rel was the B-cell tumour suppressor BTB and CNC homology 2 (Bach2). Quantitative PCR and western blot analysis confirmed loss of Bach2 in c-Rel mutant E $\mu$-Myc tumours at both 4 weeks and the terminal stages of disease. Moreover, Bach2 expression was also downregulated in c-rel-/-TCL1-Tg mice and RelA Thr505Ala mutant E $\mu$-Myc mice. Analysis of wild-type $\mathrm{E} \mu$-Myc mice demonstrated that the population expressing low levels of Bach2 exhibited the earlier onset of lymphoma seen in c-rel-/- mice. Confirming the relevance of these findings to human disease, analysis of chromatin immunoprecipitation sequencing data revealed that Bach2 is a c-Rel and NF-KB target gene in transformed human B cells, whereas treatment of Burkitt's lymphoma cells with inhibitors of the NF-KB//KB kinase pathway or deletion of $\mathrm{c}$-Rel or RelA resulted in loss of Bach2 expression. These data reveal a surprising tumour suppressor role for c-Rel in lymphoma development explained by regulation of Bach2 expression, underlining the context-dependent complexity of NF-KB signalling in cancer.

Oncogene (2016) 35, 3476-3484; doi:10.1038/onc.2015.399; published online 2 November 2015

\section{INTRODUCTION}

The tumour-promoting role of the NF-KB pathway is well established and results from its ability to regulate the expression of genes involved in multiple aspects of cancer cell biology. ${ }^{1}$ This is also true in haematological malignancies ${ }^{2}$ and in several B-cell lymphoma types, such as activated B-cell-like-diffuse large B-cell lymphomas, ${ }^{3}$ primary mediastinal large B-cell lymphoma ${ }^{4,5}$ and classical Hodgkin lymphoma ${ }^{6} \mathrm{NF}-\mathrm{KB}$ activity is required for survival and proliferation. However, the contribution of individual NF-KB subunits is generally not known. In particular, whereas NF-KB subunits have been reported to exhibit characteristics of tumour suppressors in vitro, ${ }^{1}$ it has not been investigated whether these properties have relevance to lymphoma development in vivo.

There are five NF-KB subunits in mammalian cells, RelA/p65, RelB, c-Rel, p50/p105 (NF-kB1) and p52/p100 (NF-kB2). RelA and c-Rel function as effector subunits for the IKB kinase $\beta$-dependent, canonical NF-KB pathway. ${ }^{7}$ Of these NF-KB subunits, c-Rel is most closely associated with lymphoma and was first identified as the cellular homologue of the avian Rev-T retroviral oncogene v-Rel. ${ }^{8-10}$ c-Rel is ubiquitously expressed in B cells regardless of developmental stage, although the highest levels are observed in mature B cells. ${ }^{11-13}$ c-rel knockout mice developed normally with no effects on B-cell maturation but do exhibit some immunological defects, including reduced B-cell proliferation and activation, abnormal germinal centres and reduced number of marginal zone B cells. ${ }^{14-17}$
c-Rel is distinct from other NF-KB family members in its ability to transform chicken lymphoid cells in vitro., ${ }^{8-20}$ Moreover, genomic and cytogenetic studies of human lymphomas have shown gains of chromosome 2p13, which encodes the REL gene. Amplifications and gains of REL have been detected in $\sim 50 \%$ of $\mathrm{HL}^{21-23}$ and $10-25 \%$ or $50 \%$ in two studies of primary mediastinal large B-cell lymphoma. ${ }^{4,24}$ REL has also been identified as a susceptibility locus for $\mathrm{HL}^{25}$ whereas c-Rel nuclear localisation has been identified as a poor prognostic factor in both activated B-cell-like- and germinal centre B-cell-like-diffuse large B-cell lymphomas. ${ }^{26}$

Despite this, relatively little is known about the role of c-Rel or other NF-KB subunits in c-Myc-driven lymphomas. However, a recent study of Myc-driven B-cell lymphoma in mice revealed a tumour suppressor role for RelA. ${ }^{27}$ Here, short hairpin RNA silencing of RelA did not affect progression of established lymphomas, but after cyclophosphamide treatment its loss resulted in chemoresistance as a consequence of impaired induction of senescence. ${ }^{27}$ Similarly, NF-KB was required for both therapy-induced senescence and resistance to cell death in the $\mathrm{E} \mu-\mathrm{Myc}$ mouse model of B-cell lymphoma upon expression of a degradation-resistant form of $\mathrm{IKBa}^{28} \mathrm{C}-\mathrm{Myc}$ can also inhibit expression of NF-KB2, and loss of this NF-KB subunit in the $\mathrm{E} \mu-\mathrm{Myc}$ mouse model resulted in moderately earlier onset of disease as a consequence of impaired apoptosis. ${ }^{29}$ By contrast, deletion of NF-KB1 displayed no effects on $\mathrm{E} \mu-M y c$ lymphoma

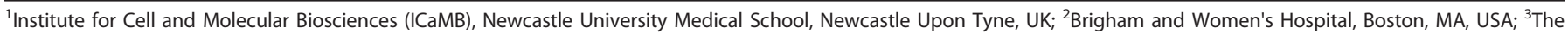

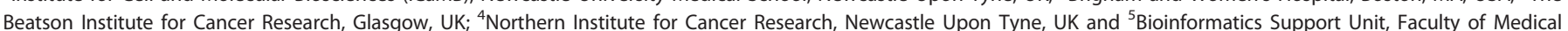

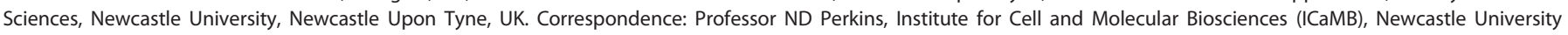
Medical School, Catherine Cookson Building, Framlington Place, Newcastle Upon Tyne, NE2 4HH, UK. 
development. ${ }^{30}$ These results imply a more complicated role for NF-KB in Myc-driven lymphoma, with both tumour-promoting and -suppressing functions being reported, although any role for c-Rel has not been established.
Here, we have investigated the role of c-Rel in mouse models of B-cell lymphomagenesis. We demonstrate that, opposite to the expected result, c-rel-/- E $\mu-M y c$ and TCL1-Tg mice exhibit earlier onset of lymphoma and that this result can be explained by c-Rel-

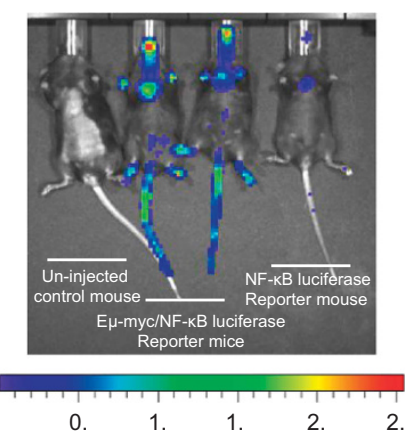

\section{b}

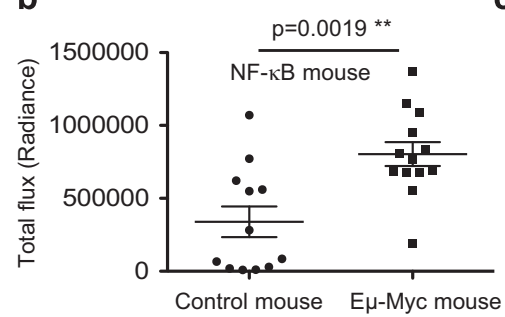

e

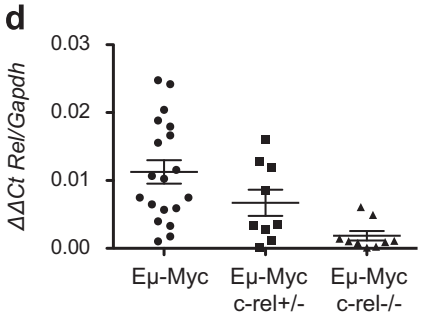

$\mathbf{f}$

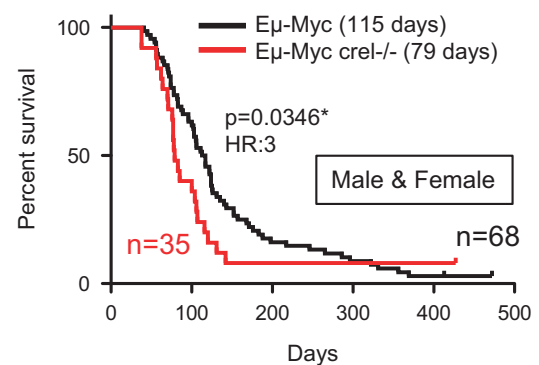

h

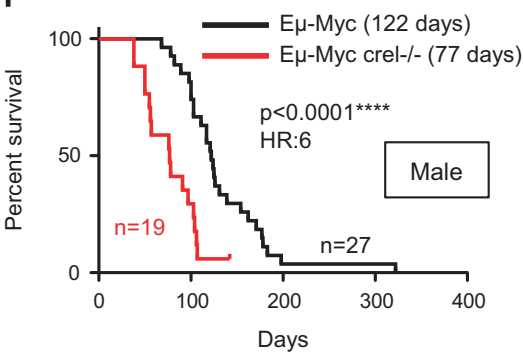

j

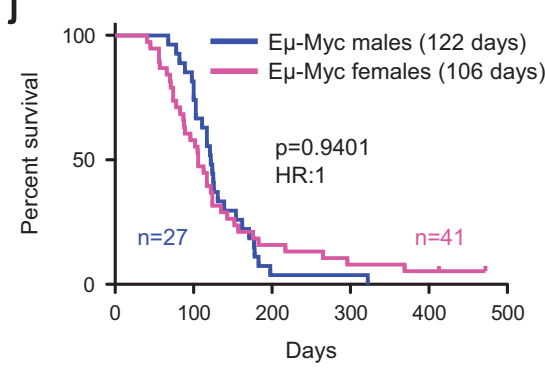

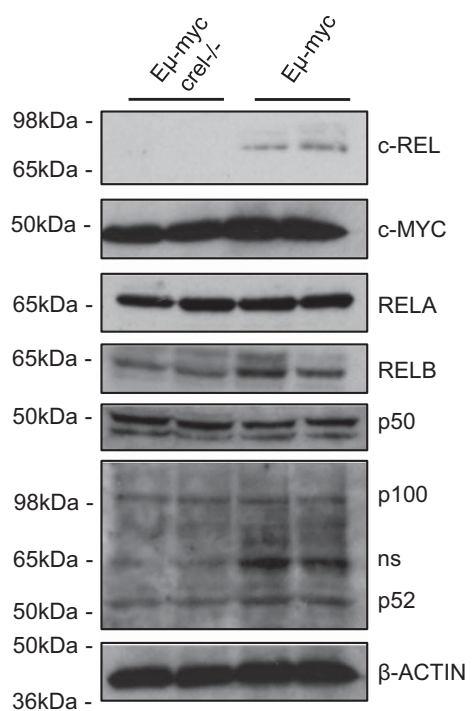

g

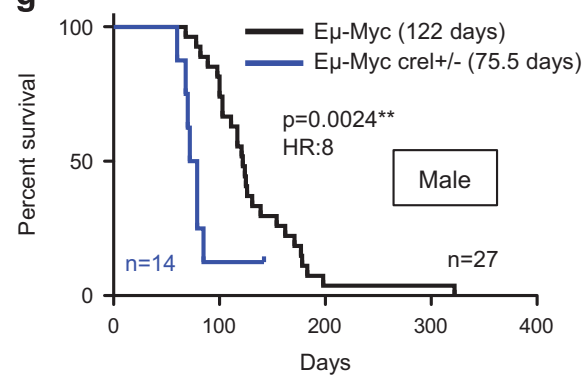

i

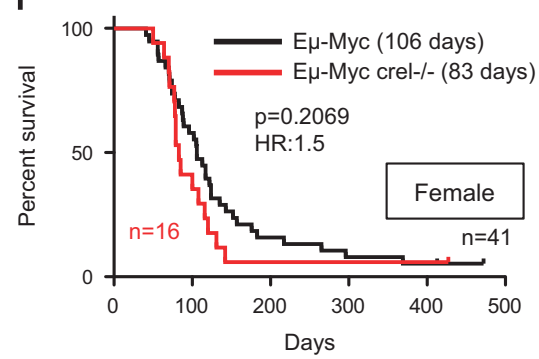

k

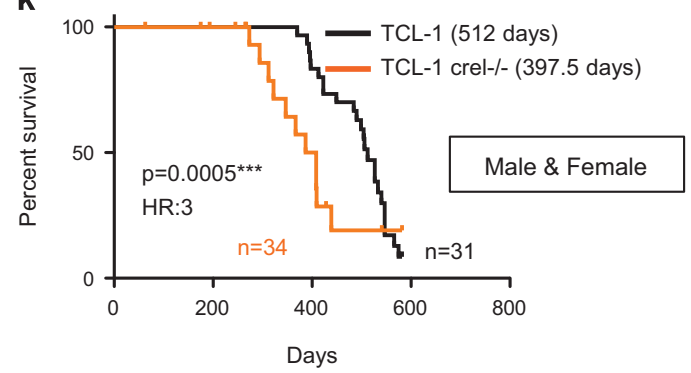

Figure 1. For caption see page 3478. 
dependent regulation of the B-cell tumour suppressor BTB and CNC homology 2 (Bach2).

\section{RESULTS}

NF-KB is active in E $\mu$-Myc-derived lymphoma

To determine if there are significant levels of NF-KB activity in Myc-driven B-cell lymphoma, with the potential to affect disease driven by this oncogene, we crossed $3 \times \mathrm{k} B$-luc (NF-KB-Luc) reporter mice onto $\mathrm{E} \mu-M y c$ transgenic mice, allowing in vivo visualisation of NF-KB activity. ${ }^{31}$ The median onset of aggressive lymphoma in $\mathrm{E} \mu$-Myc mice is between the ages of 3 and 6 months but they exhibit the hallmarks of Myc overexpression by 4 weeks. ${ }^{32}$ This analysis revealed significantly higher levels of NF-KB activity in $\mathrm{E} \mu-\mathrm{Myc}$ mice at 8 weeks of age, in lymphoid organ sites, including mesenteric/inguinal lymph nodes and thymus (Figures $1 \mathrm{a}$ and $\mathrm{b}$ ).

Loss of c-Rel results in earlier onset of $\mathrm{E} \mu$-Myc-driven lymphoma To investigate the role of $\mathrm{c}$-Rel in MYC-induced lymphomagenesis, $\mathrm{E} \mu-\mathrm{Myc} / \mathrm{c}-\mathrm{rel}-\mathrm{l}-\mathrm{mice}$ were generated. Western blot analysis confirmed no significant effects on the other NF-KB subunits or c-Myc in splenic tumour B cells, although slightly lower levels of the non-canonical NF-KB subunits $\mathrm{p} 52$ and RelB were found in c-rel-/- cells (Figure 1c). E $\mu-M y c / c-r e l+/-$ mice, despite having intermediate levels of c-Rel mRNA (Figure 1d), had almost no detectable c-Rel protein in $\mathrm{E} \mu$-Myc lymphoma cells (Figure 1e).

Given the known tumour-promoting role of c-Rel in B-cell lymphoma, we were surprised to find that $\mathrm{E} \mu-\mathrm{Myc} / \mathrm{c}-\mathrm{rel}-/-$ mice had a significantly shorter overall survival (median survival 79 days) than $\mathrm{E} \mu-M y c$ mice (median survival 115 days; Figure 1f). Earlier onset of disease was also seen in heterozygote $\mathrm{E} \mu-\mathrm{Myc} / \mathrm{c}-\mathrm{rel}+/-$ male mice (median onset 75.5 days; Figure $1 \mathrm{~g}$ ). Although survival times of male and female $\mathrm{E} \mu-\mathrm{Myc} / \mathrm{c}-\mathrm{rel}-/-$ mice were similar (77 vs 83 days, respectively; Figures $1 \mathrm{~h}$ and $\mathrm{i})$, this effect appeared more pronounced in male c-Rel mutant mice due to gender differences in wild-type $\mathrm{E} \mu$-Myc mice (122 days in males vs 106 days in females), although this difference was not statistically significant (Figure 1j).

To determine if earlier onset of disease could be seen in other lymphoma models, we generated c-rel-/- strains of $\mathrm{pE} \mu$-B29-TCL1 (TCL1-Tg) transgenic mice. ${ }^{33}$ These mice exhibit slower disease progression than in the $\mathrm{E} \mu-\mathrm{Myc}$ model and in our experiments many mice developed tumours at non-lymphoid sites (not shown). Nonetheless, c-rel-/- mice again displayed significantly reduced survival relative to wild-type TCL1 mice, confirming that this effect is not restricted to the $\mathrm{E} \mu-\mathrm{Myc}$ model (Figure $1 \mathrm{k}$ ).

Reimplanted $\mathrm{E} \mu-M y c$ tumours grow equally well in wild-type and c-rel-/- mice

These results revealed an apparent tumour suppressor role for c-Rel, but it was unclear if this resulted from an effect intrinsic to the tumour cells or from other effects of the c-rel-/- mice. Therefore, to investigate whether non-tumour cells in the wildtype and c-rel-/- mice might contribute to earlier onset of disease in c-Rel null mice, we performed a series of reciprocal tumour reimplantation studies. Tumours derived from either wild-type or c-rel-/- male E $\mu$-Myc mice were transplanted into either $\mathrm{C} 57 \mathrm{BI} / 6$ or c-rel-/- male host mice. Importantly, whether the host mice were wild type or c-rel-/- did not affect the rate of c-rel-/- lymphoma growth (Figures 2a and c). A more mixed effect was seen with reimplanted wild-type $\mathrm{E} \mu$-Myc cells, where increased lymphoma growth was seen at some sites but not others in the c-rel-/- host mice (Figure 2c). Reimplanted c-rel-/- lymphomas were also slower to develop than wild type ( 4 weeks vs 2 weeks) but this may reflect the reduced viability of $\mathrm{E} \mu-\mathrm{Myc} / \mathrm{c}-\mathrm{rel}-/-$ tumour cells after thawing frozen samples (Figure $2 \mathrm{~d}$ ). This analysis does not rule out a contribution from the non-tumour background in the development of $\mathrm{E} \mu-\mathrm{Myc}$ lymphoma in these mice. However, given that we saw no effects of the host animal on the growth of reimplanted c-rel-/- cells, we investigated if there were intrinsic differences between wild-type and c-rel-/- lymphoma cells.

Figure 1. c-Rel functions as a tumour suppressor in $\mathrm{E} \mu$-Myc-driven B-cell lymphoma in mice. (a) Representative image of in vivo NF- $\mathrm{B}$

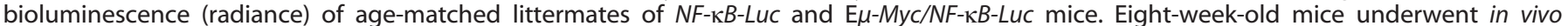
imaging using the IVIS Spectrum system (Perkin Elmer, Beaconsfield, UK) after being intraperitoneally administration with $150 \mathrm{mg} / \mathrm{kg}$ VivoGlo D-luciferin (Promega, Southampton, UK) dissolved in sterile phosphate-buffered saline. Ten-min post-D-luciferin-administration, mice were imaged using a photon emission over $5 \mathrm{~min}$, under isoflurane anaesthesia. Luminescence was seen in the thymic area and also in the tails and other exposed regions of the $\mathrm{E} \mu-M y c / N F-\kappa B$ - Luc mice, the latter likely due to a higher number of circulating lymphocytes with increased NF- $\mathrm{B} B$

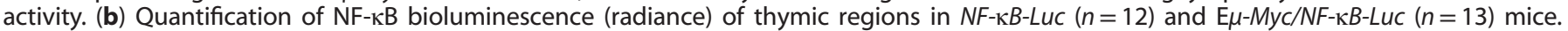
Bioluminescence was quantified using the Living Image software version 4.3.1 (Perkins Elmer) and region of interest tool. Data shown as mean \pm s.e.m., ${ }^{*} P<0.01$, unpaired Student's $t$-tests. For all tests, where appropriate, analyses were undertaken to test for normal distribution. (c) Western blot analysis of the NF- $\mathrm{KB}$ subunits, c-REL, RELA, RELB, p100/p52 and p50 together with c-MYC in extracts prepared from E $\mu$-Myc and $\mathrm{E} \mu-\mathrm{Myc} / \mathrm{c}-\mathrm{rel}-/-$ mouse tumorigenic spleens. Whole-cell extracts were prepared from $\mathrm{E} \mu-M y c$ or E $\mu-M y c / c-r e l-/-$ tumour cell suspensions. Cell pellets were washed with ice-cold phosphate-buffered saline and lysed using PhosphoSafe Extraction Reagent (Merck Millipore, Watford, UK). Antibodies used were c-Rel (sc-71 Santa Cruz, Insight Biotechnology, Wembley, UK), c-Myc (sc-42 Santa Cruz), RelA (sc-372 Santa Cruz), RelB (4954 Cell Signaling, Hitchin, UK), p50 (06-886 Merck Millipore), p100/p52 (sc-848 Santa Cruz) and $\beta$-Actin (A5441 Sigma-Aldrich, Gillingham, UK). (d) Quantitative-PCR analysis showing relative Rel expression in end-stage tumorigenic spleens from $\mathrm{E} \mu-M y c(n=20), \mathrm{E} \mu-M y c / c-$ relt/- $(n=12)$ and $\mathrm{E} \mu-\mathrm{Myc} / \mathrm{c}-\mathrm{rel}-/-(n=11)$ mice. Data shown as mean \pm s.e.m., each point is an individual mouse. (e) Western blot analysis of c-REL levels in tumorigenic spleens from $\mathrm{E} \mu-\mathrm{Myc}, \mathrm{E} \mu-\mathrm{Myc} / \mathrm{c}-\mathrm{rel} / \mathrm{l}-$ and $\mathrm{E} \mu-\mathrm{Myc} / \mathrm{c}-\mathrm{rel}-/-$ mice. (f-j) Reduced survival of $\mathrm{E} \mu-\mathrm{Myc} / \mathrm{c}-\mathrm{rel}+/-$ and $\mathrm{E} \mu-\mathrm{Myc} / \mathrm{c}-\mathrm{rel}-/$ - mice. Kaplan-Meier plots showing survival curves for $\mathrm{E} \mu-M y c$ and (f) $\mathrm{E} \mu-M y c / c-r e l-/-$ mice, (g) $\mathrm{E} \mu-M y c / c-r e l+/-$ male mice, (h) $\mathrm{E} \mu-M y c / c-r e l-/-$ male mice, (i) E $\mu-M y c / c-r e l-/-$ female mice and relative survival of male versus female E $\mu$-Myc mice is shown in (j). P-values (Mantel-Cox test) and hazard ratios are shown. (k) Kaplan-Meier plot showing reduced survival of TCL1/c-rel-/- mice. Animal handling, husbandry and experimentation were undertaken in compliance with UK Home Office regulations under project licences and approved by the local ethical review committee. All mice used in these experiments were on C57BL/6 background and bred at the Comparative Biology Centre, Newcastle

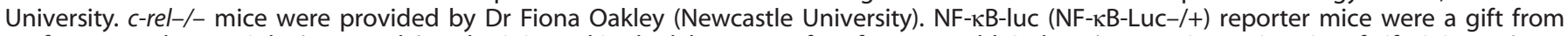
Professor Matthew Wright (Newcastle) and originated in the laboratory of Professor Harald Carlsen (Norwegian University of Life Sciences). E $\mu$ Myc and TCL1-Tg mice were purchased from The Jackson Laboratory (Bar Harbor, ME, USA). E $\mu$-Myc/c-rel+/- offspring were generated by mating c-rel-/- female mice with $\mathrm{E} \mu-\mathrm{Myc}$ male mice. E $\mu-M y c / c-r e l-/-$ mice were then generated by crossing $\mathrm{E} \mu-\mathrm{Myc} / \mathrm{c}-\mathrm{rel}+/-\mathrm{males}$ with $\mathrm{c}-\mathrm{rel}-/-$ female mice. In TCL1-Tg mice, a human TCL1 coding sequence is expressed from a B29 minimal promoter, coupled with the IgH intronic enhancer resulting in B- and T-cell expression. TCL1/c-rel-/- offspring were generated as for E $\mu-M y c$ by mating $c$-rel-/- female mice with TCL1$\mathrm{Tg}$ male mice. All mice were designated to an experimental group-dependent on their strain and no blinding was undertaken during analysis. For survival analysis, mice were monitored daily and were killed at predetermined end points, defined as the animal becoming moribund, losing bodyweight/condition and/or having palpable tumour burden at any lymphoid organ site, at which point animals underwent necropsy. Kaplan-Meier survival curves were drawn using GraphPad Prism (Version 5.0, GraphPad Software, La Joll, CA, USA). 
a

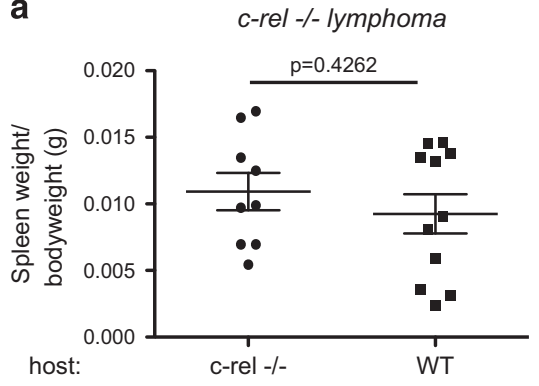

b

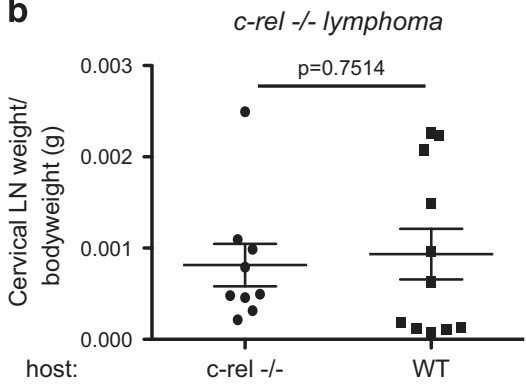

d

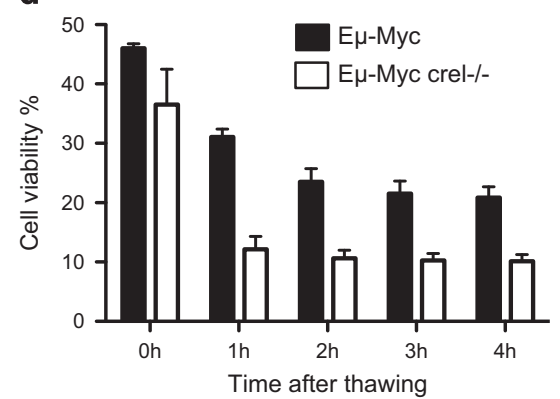

C

\begin{tabular}{|c|c|c|c|c|}
\hline Tumour & \multicolumn{2}{|c|}{ Eн-myc crel-/- } & \multicolumn{2}{|c|}{ 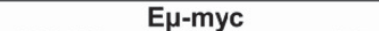 } \\
\hline Host animal & C57BI/6 & crel-- & C57BI/6 & crel-/- \\
\hline Lymphoid organ & \multicolumn{2}{|c|}{ Organ (weight/bodyweight) (mg) } & \multicolumn{2}{|c|}{ Organ (weight/bodyweight) (mg) } \\
\hline Inguinal LN & $2.1 \pm 0.7$ & $0.8 \pm 0.1$ & $1.1 \pm 0.2$ & $1.3 \pm 0.3$ \\
\hline Brachial LN & $2.3 \pm 0.8$ & $1.4 \pm 0.3$ & $0.9 \pm 0.2$ & $2.0 \pm 0.4^{*}$ \\
\hline Mesenteric LN & $3.6 \pm 0.8$ & $4.5 \pm 0.6$ & $2.4 \pm 0.4$ & $6.8 \pm 1.5^{*}$ \\
\hline Spleen & $9.2 \pm 1.5$ & $10.9 \pm 1.4$ & $12.7 \pm 1.1$ & $15.2 \pm 1.7$ \\
\hline Thymus & $10.1 \pm 3.2$ & $4.9 \pm 1.0$ & $2.5 \pm 0.3$ & $5.1 \pm 0.9^{*}$ \\
\hline Cervical LN & $0.9 \pm 0.3$ & $0.8 \pm 0.2$ & $1.6 \pm 0.5$ & $1.3 \pm 0.3$ \\
\hline \multicolumn{5}{|l|}{ Non-lymphoid organ } \\
\hline Liver & $51.1 \pm 1.8$ & $45.0 \pm 0.7$ & $53.4 \pm 2.5$ & $55.8 \pm 2.4$ \\
\hline Kidney & $5.9 \pm 0.3$ & $6.5 \pm 0.2$ & $5.9 \pm 0.2$ & $6.1 \pm 0.2$ \\
\hline Lung & $7.2 \pm 0.4$ & $7.2 \pm 0.4$ & $7.0 \pm 0.2$ & $8.4 \pm 0.5$ \\
\hline
\end{tabular}

e

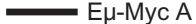

- - E E-Myc crel-/- A
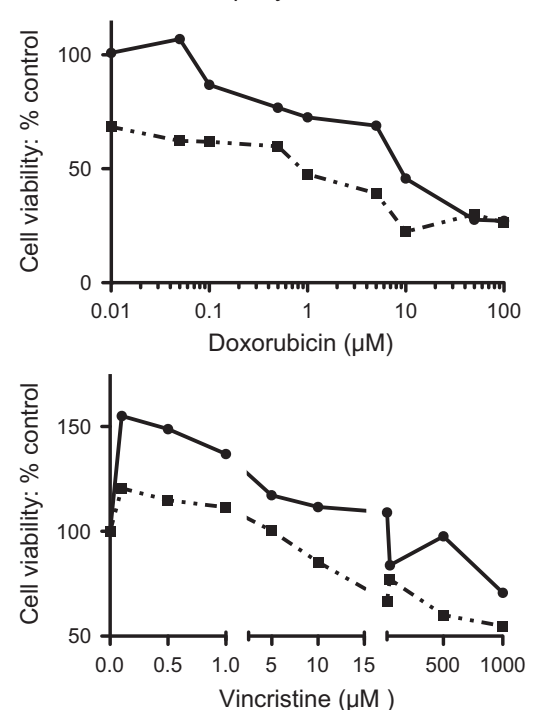
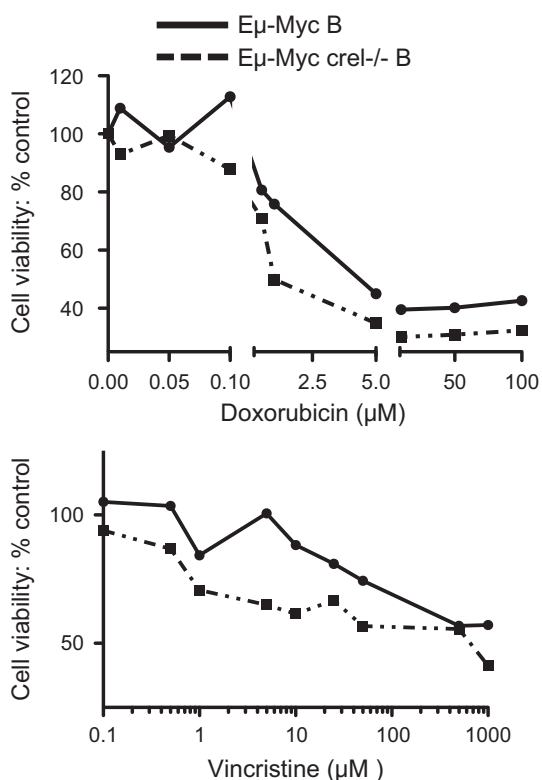

Doxorubicin $\mathrm{GI}_{50}$

Eн-MyсA: $4.2 \mu \mathrm{M}$

E $\mu-M y c B: 9.5 \mu \mathrm{M}$

Eu-Myc crel-/- A: $1.1 \mu \mathrm{M}$

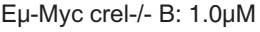

Vincristine $\mathrm{GI}_{25}$

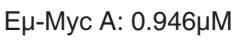

E $\mu$-Myc B: $0.067 \mu \mathrm{M}$

E $\mu$-Myc crel-/- A: $0.014 \mu \mathrm{M}$

E $\mu$-Myc crel-/- B: $0.001 \mu \mathrm{M}$

Figure 2. E $\mu-M y c / c-r e l-/-$ tumours grow equally well in wild-type and c-rel-/- mice and are more sensitive to apoptotic stimuli. (a, b) Reimplanted $\mathrm{E} \mu-\mathrm{Myc} / \mathrm{c}-\mathrm{rel}-/-$ tumours grow equally well in wild-type and $c$-rel-/- mice. Lymph node tumours derived from three different $\mathrm{E} \mu$ Myc/c-rel-/- mice were reimplanted in parallel into either three wild-type (C57BI/6) or three c-rel-/- host mice. Four weeks after implantation, the mice were killed and tumour sizes at different sites were assessed. Data shown here are from the spleen (a) and cervical lymph nodes (b). Data representing mean \pm s.e.m. and $P$-values were calculated using Student's unpaired $t$-tests. (c) Tumour burden in lymphoid organs (weight of organ/bodyweight of animal in gram) following reimplantation of either $\mathrm{E} \mu-\mathrm{Myc}$ or $\mathrm{E} \mu-\mathrm{Myc} \mathrm{c}-\mathrm{rel}-/-$ tumour cells into either $\mathrm{C} 57 \mathrm{BI} / 6$ or c-rel-/- mice. Data shown are the means of three independent tumours each implanted into three mice \pm s.e.m. ${ }^{*} P<0.05$ in an unpaired Student's $t$-test, but otherwise there were no significant differences between tumour burden in wild-type and c-rel knock-out animals at any of

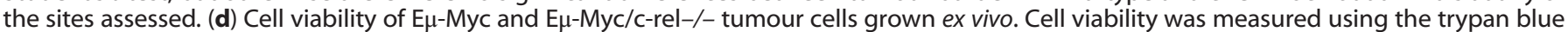
exclusion assay over a 4-h period after freeze thawing. (e) $\mathrm{E} \mu-\mathrm{Myc} / \mathrm{c}-\mathrm{rel}-/-$ tumour cells are more sensitive to apoptotic stimuli. Freshly isolated $\mathrm{E} \mu-\mathrm{Myc}$ or $\mathrm{E} \mu-\mathrm{Myc} / \mathrm{c}-\mathrm{rel}-/-$ lymph node tumour cells $\left(5 \times 10^{5}\right.$ per well) were seeded into 96 -well plates. Increasing concentrations of the chemotherapeutic agents, doxorubicin (Sigma-Aldrich) or vincristine (Sigma-Aldrich) or solvent controls were added to three replicate wells. After $96 \mathrm{~h}$, viability was quantified using the CellTiter96 $\mathrm{AQ}_{\text {ueous }}$ One Solution Cell Proliferation Assay (MTS; Promega), according to the manufacturer's instructions. Single-cell suspensions were prepared from tumour-bearing organs of E $\mu-M y c$ and E $\mu-M y c / c-r e l-/-$ mice upon necropsy. These were then used for downstream analyses or frozen in $90 \%$ fetal bovine serum/10\% dimethyl sulfoxide for long-term storage and transplantation. For reciprocal microenvironment experiments, $2 \times 10^{6} \mathrm{E} \mu-\mathrm{Myc} / \mathrm{c}-\mathrm{rel}-\mathrm{l}-\mathrm{lymph}$ node tumour cells from male mice were transplanted intravenously via the lateral tail vein into 8-week-old male C57BL/6 or c-rel-/- recipients. Mice were necropsied when they became moribund and the tumour burden assessed. C57BL/6 mice used for reimplantation studies were purchased from Charles River (Margate, UK). 
c-rel-/- B-cell lymphomas are more sensitive to apoptotic stimuli c-Rel and the other NF-KB subunits can contribute towards tumorigenesis by inducing the expression of antiapoptotic genes ${ }^{34}$ and, consistent with this and the results in Figure $2 d$, we found that when cultured ex vivo, tumour cell isolates from $\mathrm{E} \mu$ Myc/c-rel-/- mice showed increased sensitivity to the R-CHOP therapy components doxorubicin and vincristine (Figure 2e). Therefore, $\mathrm{E} \mu-M y c / c-r e l-/-$ cells appear more prone to apoptosis a

\begin{tabular}{|c|c|c|c|c|c|}
\hline Name & Symbol & C-rel -I- M & c-rel +/- M & c-rel -l-F & c-rel +/- F \\
\hline $\begin{array}{l}\text { MAK16 homolog (S. } \\
\text { cerevisiae) }\end{array}$ & Mak16 & 2.40 & 0.63 & 1.82 & 0.79 \\
\hline $\begin{array}{c}\text { BTB and CNC } \\
\text { homology } 2\end{array}$ & Bach2 & 1.46 & 0.58 & 1.53 & 0.77 \\
\hline $\begin{array}{l}\text { transmembrane } \\
\text { protein } 68\end{array}$ & Tmem68 & 1.07 & 0.55 & 0.76 & 0.43 \\
\hline $\begin{array}{l}\text { processing of } \\
\text { precursor } 4\end{array}$ & Pop4 & 0.91 & 0.42 & 0.45 & 0.29 \\
\hline $\begin{array}{l}\text { heparan-alpha- } \\
\text { glucosaminide N- } \\
\text { acetyltransferase }\end{array}$ & Hgsnat & 0.79 & 0.35 & 0.56 & 0.40 \\
\hline $\begin{array}{l}\text { transmembrane } \\
\text { protein } 254 a\end{array}$ & Tmem254a & 0.76 & 0.34 & 0.82 & 0.84 \\
\hline $\begin{array}{l}\text { GA repeat binding } \\
\text { protein, beta } 2\end{array}$ & Gabpb2 & 0.73 & 0.21 & 0.81 & 0.26 \\
\hline $\begin{array}{l}\text { NLR family, CARD } \\
\text { domain containing } 4\end{array}$ & Nirc4 & 0.69 & 0.26 & 0.61 & 0.31 \\
\hline limb-bud and heart & Lbh & -0.61 & -0.36 & -0.55 & -0.63 \\
\hline $\begin{array}{l}\text { tryptophanyl tRNA } \\
\text { synthetase } 2\end{array}$ & Wars2 & -0.70 & -0.43 & -0.67 & -0.36 \\
\hline cyclin D1 & Cond1 & -0.72 & -0.37 & -0.88 & -0.79 \\
\hline $\begin{array}{l}\text { phosphatidylserine } \\
\text { decarboxylase, } \\
\text { pseudogene } 3\end{array}$ & Pisd-ps3 & -0.94 & -0.43 & -0.84 & -0.51 \\
\hline $\begin{array}{l}\text { kallikrein 1-related } \\
\text { peptidase b22 }\end{array}$ & Klk1b22 & -0.96 & -0.41 & -0.41 & -0.70 \\
\hline LIM domain and actin & Lima1 & -1.75 & -1.46 & -1.75 & -1.32 \\
\hline
\end{tabular}
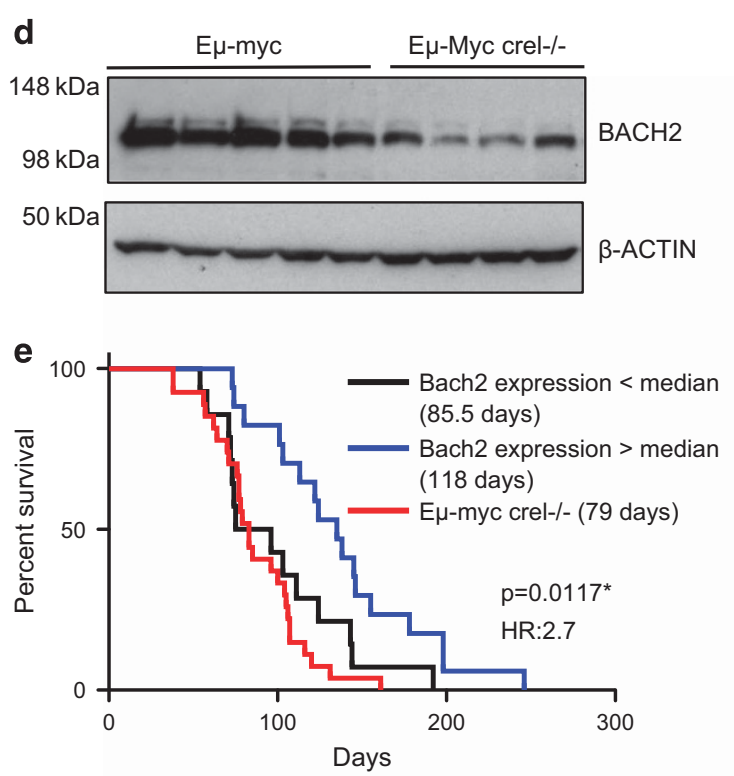

b

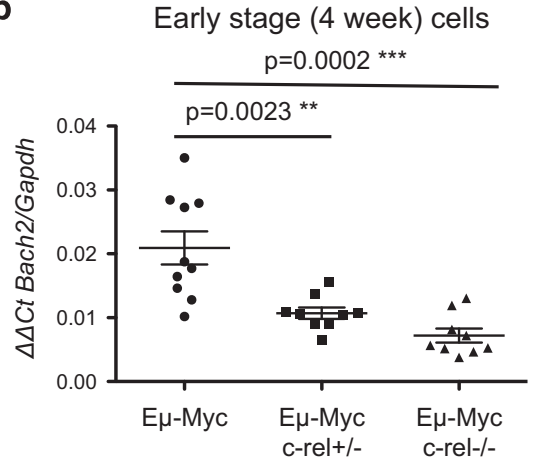

End-stage tumours

C

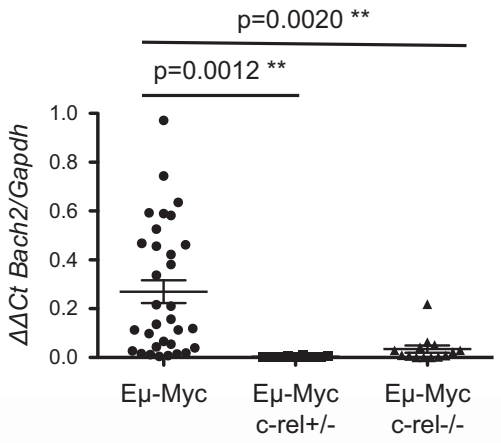

f

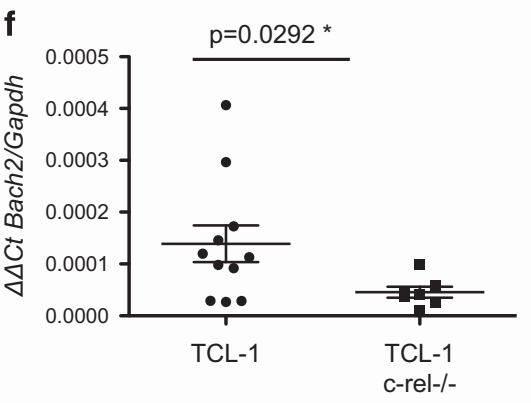

g

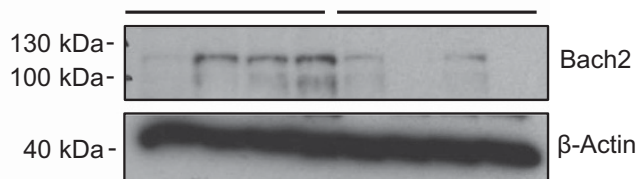

h

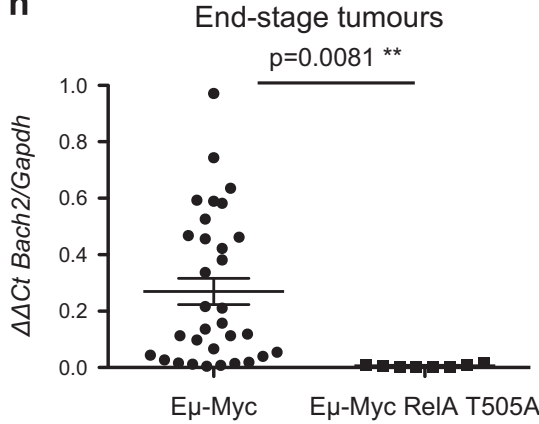

i

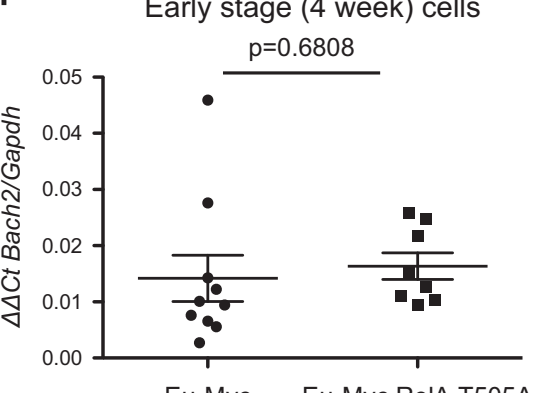

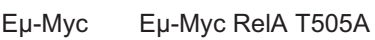


when compared with their wild-type equivalents. These effects are consistent with the known antiapoptotic effects of c-Rel but did not explain the earlier onset of disease in c-Rel null mice.

The tumour suppressor Bach2 is a c-Rel target gene

The p53 and ARF pathways are frequently disrupted in $\mathrm{E} \mu-\mathrm{Myc}$ lymphoma. ${ }^{35}$ However, we found that mRNA levels of p53 target genes, such as Mdm2 and Bax, as well as the CDKN2A gene that encodes the ARF protein were similar across end-stage $E \mu-M y c$ and $\mathrm{E} \mu-\mathrm{Myc} / \mathrm{c}-\mathrm{rel}-/-$ tumour cells (not shown), suggesting that c-Rel loss does not lead to further disruption of these pathways. Moreover, no significant differences in BCL2L1 mRNA, an NF-KB target gene that encodes the antiapoptotic protein $\mathrm{BCl}-\mathrm{xL}^{34}$ were observed (not shown).

We therefore wanted to learn more about other changes in gene expression associated with the earlier onset of lymphoma in the $\mathrm{E} \mu$ $\mathrm{Myc} / \mathrm{c}-\mathrm{rel}-/-$ mice. Consequently, we decided to perform microarraybased genome-wide mRNA expression analyses on B cells from 4week-old $\mathrm{E} \mu-\mathrm{Myc}, \mathrm{E} \mu-\mathrm{Myc} / \mathrm{c}-\mathrm{rel}+/-$ and $\mathrm{E} \mu-M y c / c-r e l-/-$ mice.

Analysis of these microarray data identified a number of genes misregulated in $\mathrm{E} \mu-\mathrm{Myc} / \mathrm{c}-\mathrm{rel}-/-$ mice (Figure 3a). Of these, the loss of expression of Bach2 in c-Rel mutant mice was of particular interest. Bach2 is a lymphoid-specific transcription factor with a role in $\mathrm{B}$-cell development ${ }^{36}$ and the response to oxidative stress. ${ }^{37,38}$ Bach2 has also been identified as a tumour suppressor in acute lymphoblastic leukaemia. ${ }^{39}$ Importantly, quantitative PCR analysis confirmed that Bach2 mRNA expression is lost in B cells from 4-week-old $\mathrm{E} \mu$-Myc/c-rel+/- and $\mathrm{E} \mu-\mathrm{Myc} / \mathrm{c}-\mathrm{rel}-/-$ mice (Figure $3 \mathrm{~b}$ ), and also from the tumours taken from mice killed with end-stage disease (Figure $3 c$ ). Bach2 protein levels were also significantly reduced in the $\mathrm{E} \mu-\mathrm{Myc} / \mathrm{c}-\mathrm{rel}-/-$ tumours (Figure $3 \mathrm{~d}$ ). Quantitative PCR also validated a number of other potential targets identified in the microarray, including Cyclin D1 and Lima1 (not shown). Although Bach2 levels were reduced in normal, untransformed B cells from c-rel-/- 4-week-old mice, this was not a statistically significant effect (not shown).
Although Bach2 mRNA levels are uniformly low in all $\mathrm{E} \mu-\mathrm{Myc} / \mathrm{c}$ rel-/- and c-rel+/- lymphoma samples analysed, we observed a wide range of Bach2 mRNA expression in end-stage wild-type $\mathrm{E} \mu$ Myc tumours (Figure 3c). We were therefore interested in whether this would correlate with survival of these wild-type $\mathrm{E} \mu-M y c$ mice. Significantly, we found that $\mathrm{E} \mu-M y c$ mice with below-the-median level of Bach2 mRNA displayed decreased survival, with a median survival of 85.5 versus 135 days for mice with high Bach2 levels (Figure 3e). Therefore, wild-type mice with reduced levels of Bach2 have a very similar pattern of lymphoma onset to that seen in the c-rel-/- mice, providing a potential mechanism that allows this NF-KB subunit to function as a tumour suppressor in this model of c-Myc-driven B-cell lymphoma (Figure 3e).

To determine the generality of these effects we also analysed Bach2 levels in the spleens of TCL1-Tg mice, where we observed a reduction in mRNA and protein levels (Figures $3 f$ and $g$ ). Furthermore, in a separate NF-kB knock in mouse model, where the RelA subunit was engineered to contain a Thr505Ala mutation in its transactivation domain, a site previously shown to affect NFKB function, ${ }^{40}$ loss of Bach2 expression was also seen in end-stage lymphoma cells (Figure $3 \mathrm{~h}$ ) but not in 4-week B cells from $\mathrm{E} \mu-\mathrm{Myc}$ mice (Figure 3i). The RelA T505A mouse will be described in more detail elsewhere.

Although these data indicated that Bach2 expression is regulated by c-Rel, Bach2 has not been previously described as a direct NF-KB target gene. To address this, we analysed chromatin immunoprecipitation sequencing (ChIP-Seq) data from the Epstein-Barr-virus-transformed human lymphoblastoid $\mathrm{B}$-cell line GM12878. ${ }^{41}$ This revealed that the Bach2 promoter is bound by c-Rel together with the other NF-KB subunits, RelA, RelB and p52 (Figure 4a). Moreover, further analysis of ChIP-Seq data obtained for the RelA NF-KB subunit by the Encode consortium confirmed that Bach2 is an NF-KB target gene in multiple B-cell lines (not shown). Consistent with these data, analysis of the human Burkitt lymphoma cell line Daudi, where NF-KB subunits had been depleted by CRISPR/Cas9 mutagenesis, revealed that loss of either

Figure 3. Expression of the B-cell tumour suppressor Bach2 is dependent on c-Rel in E $\mu$-Myc lymphoma. (a) Table showing genes whose expression is regulated by $\mathrm{c}-\mathrm{Rel}$ from microarray analysis of bone marrow-derived $\mathrm{B}$ cells from 4-week-old $\mathrm{E} \mu-\mathrm{Myc}$, $\mathrm{E} \mu-\mathrm{Myc} / \mathrm{c}-\mathrm{rel}+/-$ and $\mathrm{E} \mu-\mathrm{Myc/}$ c-rel-/- mice. Fold changes shown are compared with equivalent wild-type cells and are in log2 (a positive number indicates higher expression in wild-type cells). Bone marrow-derived B cells were purified from 4-week-old E $\mu$-Myc or E $\mu$-Myc/c-rel+/-, E $\mu$-Myc/c-rel+/- mice using CD19 microbeads (MACS Miltenyi Biotec, Surrey, UK). Total B-cell RNA, purified using the PeqGold total RNA extraction kit (Peqlab, VWR, Lutterworth, UK), was then used for microarray analysis at Cambridge Genomic Services (University of Cambridge, Cambridge, UK) using the Illumina mouse WG-6 Expression BeadChip system (San Diego, CA, USA). These data were background corrected in Illumina GenomeStudio and subsequent analysis proceeded using the lumi and limma packages in R (Bioconductor, Seattle, WA, USA). ${ }^{46-48}$ Variant stabilisation transform and robust spline normalisation were applied in lumi. Differential expression was detected using linear models and empirical Bayes statistics in limma. A list of genes for each comparison was generated using a Benjamini-Hochberg false discovery rate-corrected $P$-value of 0.05 as a cutoff. (b, c) Confirmation that Bach2 mRNA levels are c-Rel regulated. Quantitative-PCR (q-PCR) showing relative Bach2 expression in (b) bone marrow-derived B cells from E $\mu-M y c(n=10), \mathrm{E} \mu-M y c / c-r e l+/-(n=9)$ and $\mathrm{E} \mu-M y c / c-r e l-/-(n=9)$ mice and $(\mathbf{c})$ end-stage tumorigenic spleens from $\mathrm{E} \mu-\mathrm{Myc}(n=30), \mathrm{E} \mu-M y c / c-r e l+/-(n=12)$ and $\mathrm{E} \mu-M y c / c-r e l-/-(n=11)$ mice. q-PCR was performed in triplicate on 20 ng cDNA (Reverse Transcriptase kit, Qiagen, Crawley, UK), using predesigned Bach2 Quanititect Primer assays (Qiagen). Samples were run and analysed on a Rotor-gene Q system (Qiagen), using murine Gapdh primers as an internal control. All cycle threshold values were normalised to Gapdh levels using the Pfaffl method. ${ }^{49}$ Data represent mean \pm s.e.m. ${ }^{* *} P<0.01,{ }^{* * *} P<0.001$ (unpaired Student's $t$-test). (d) Bach2 protein levels are reduced in $\mathrm{E} \mu-\mathrm{Myc} / \mathrm{c}-\mathrm{rel}-/-$ mice. Whole-cell extracts were prepared from E $\mu$-Myc or E $\mu$-Myc/c-rel-/- tumourigenic spleens. Cell pellets were washed with ice-cold phosphate-buffered saline, and lysed using PhosphoSafe Extraction Reagent (Merck Millipore), according to the manufacturer's protocols. Western blot analysis was performed using antibodies to BACH2 (ab83364 Abcam, Cambridge, UK) or the loading control $\beta$-ACTIN (A5441 Sigma-Aldrich). (e) Low levels of Bach2 mRNA correlate with poor survival in wild-type E $\mu$-Myc mice. Kaplan-Meier analysis of the survival of mice with below and above the median levels of Bach2 mRNA (from data in c). Also shown for comparison is the survival data from $\mathrm{E} \mu-\mathrm{Myc} / \mathrm{c}-\mathrm{rel}-/-$ mice shown in Figure 1f. (f) Bach2 mRNA levels are c-Rel regulated in TCL1-Tg mice. q-PCR showing relative Bach2 expression in end-stage tumorigenic spleens from TCL1-Tg $(n=11)$ and TCL1-Tg/c-rel-/- $(n=7)$ mice. Data represent mean \pm s.e.m. ${ }^{*} P<0.05$. (g) Bach2 protein levels are reduced in TCL1/c-rel-/- mice. Whole-cell extracts were prepared from TCL1-Tg or TCL1/c-rel-/tumourigenic spleens and western blot analysis was performed as indcated. (h, i) Low Bach2 mRNA levels in RelA T505A mice. q-PCR showing relative Bach2 expression in (h) end-stage tumorigenic spleens from $\mathrm{E} \mu-\mathrm{Myc}(n=30)$ and $\mathrm{E} \mu-\mathrm{Myc} / \mathrm{rela}{ }^{T 505 A}(n=8)$ mice and (i) bone marrowderived B cells from $\mathrm{E} \mu-\mathrm{Myc}(n=10)$ and $\mathrm{E} \mu-\mathrm{Myc} / \mathrm{rela}{ }^{T 505 A}(n=8)$ mice. Note, data from wild-type E $\mu$-Myc mice are the same as shown in c. Data

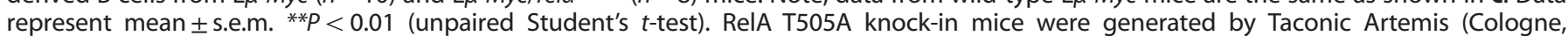
Germany) using C57BI/6 ES cells. 


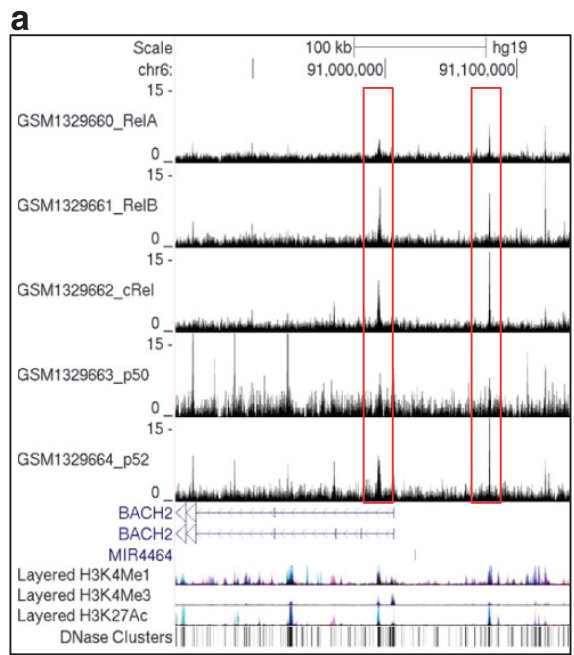

b

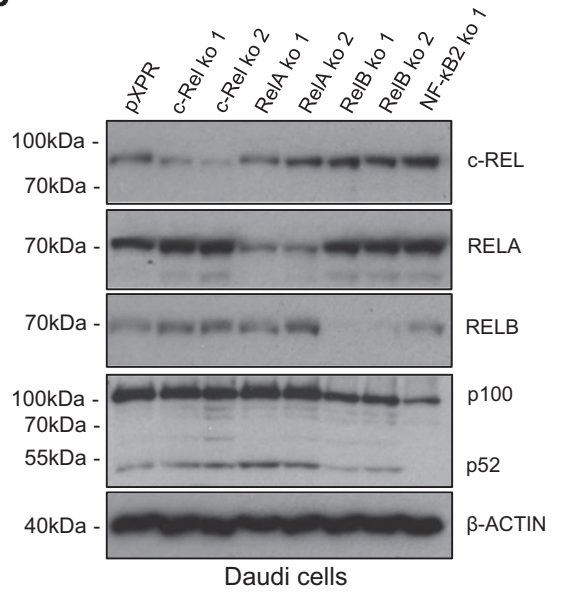

C

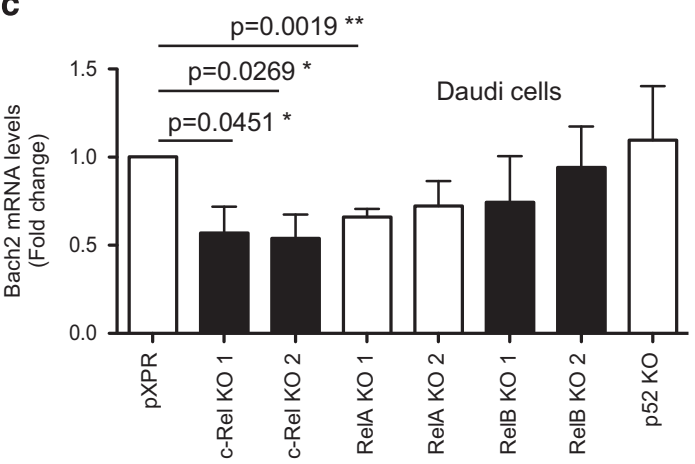

d

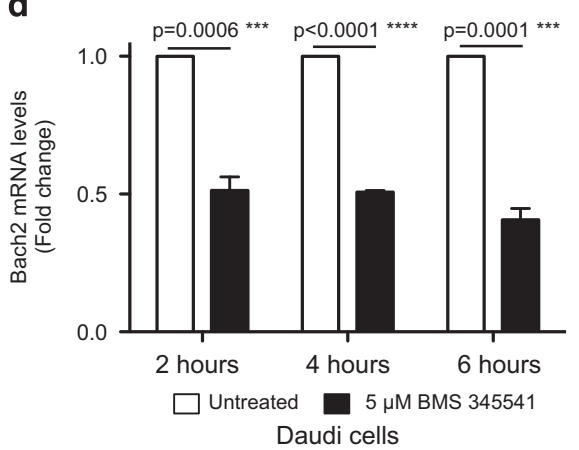

e

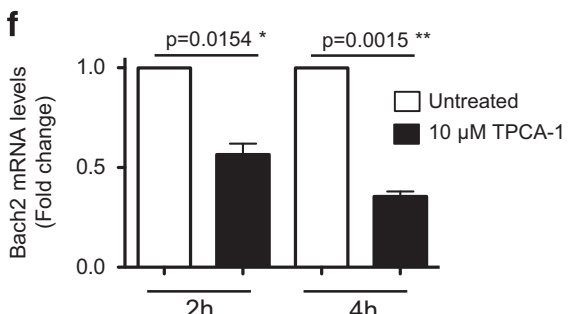

g

BMS 345541: - +

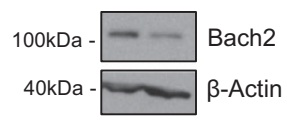

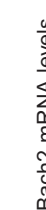

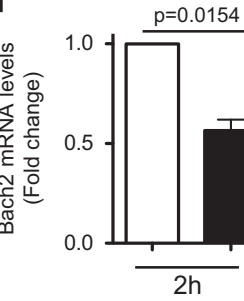

i
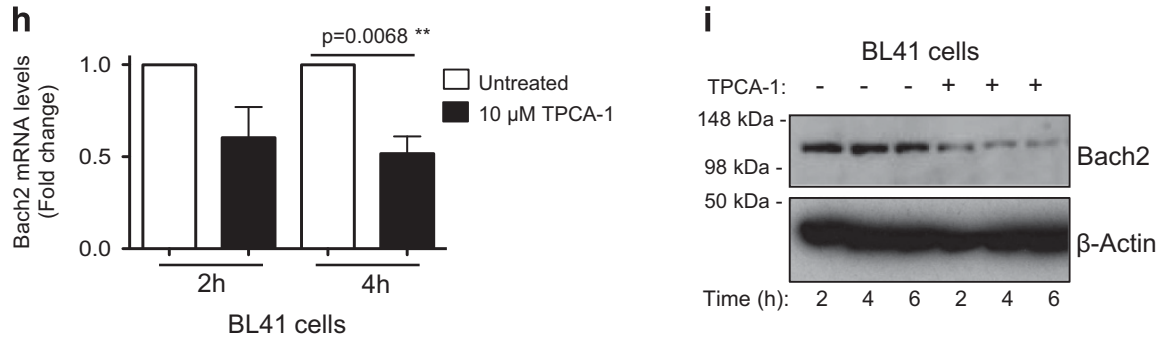

c-Rel or RelA reduced Bach2 mRNA levels (Figures $4 \mathrm{~b}$ and c). However, no effect on Bach2 protein level was seen (not shown) suggesting functional compensation between c-Rel and RelA in these cells, as has been reported previously for these subunits. ${ }^{42}$ Treatment of Daudi cells with the IKB kinase- $\beta$ inhibitors BMS 345541 or TPCA-1, which inhibit the classical NF-KB pathway and so target both RelA and c-Rel, did result in loss of both Bach2 mRNA and protein (Figures $4 \mathrm{~d}$ and $\mathrm{g}$ ), and similar results were seen in the Burkitt cell line BL41 treated with TPCA-1 (Figures $4 \mathrm{~h}$ and $\mathrm{i}$ ).
The role of c-Rel in B-cell lymphoma

Given the large number of studies indicating tumour-promoting roles for c-Rel in lymphoma, ${ }^{2-6,21-26,43}$ our results showing earlier onset of disease in c-Rel mutant mice were surprising. However, a number of in vitro studies have, in addition to their known tumour-promoting activities, revealed tumour suppressor functions for NF-KB subunits. ${ }^{1}$ Moreover, previous reports using mouse models of c-Myc-driven lymphoma have demonstrated that through induction of therapy-induced senescence, NF-KB can function as a tumour suppressor in this context. ${ }^{27,28}$ Importantly, 
Figure 4. Bach2 is an NF- $\kappa B$ target gene on human B-cell malignancies. (a) ChIP-Seq data showing NF- $\mathrm{B}$ subunit binding in the region of the human $\mathrm{BACH} 2$ gene in the Epstein-Barr-virus-transformed lymphoblastoid B-cell line (LCL) GM12878. ChIP-Seq data were extracted from a previously published analysis of the Epstein-Barr-virus-transformed LCL GM12878 using validated anti-RelA, RelB, c-Rel, p52 and p50 antibodies. ${ }^{41}$ Reads from all ChIP-Seq experiments were mapped to the hg19/GRCh37 build of the human genome using the UCSC genome browser. (b, c) c-Rel and RelA regulate Bach2 mRNA levels in Daudi cells. In $\mathbf{b}$ western blot analysis shows depletion of NF- $\kappa B$ subunits in the Daudi Burkitt's lymphoma cell line using CRISPR/Cas9 mutagenesis. In c q-PCR shows relative Bach2 expression in the Daudi cells with mutated NF- $\kappa$ B subunits. Data are obtained from separately derived pools of Daudi Cas9+ cells that express either a control single-guide RNA (sgRNA) against GFP (pXPR) or an sgRNA against the indicated NF-kB subunit. RNA or protein was extracted for either q-PCR (b) or western blot (c) analysis, as indicated. Daudi Cas9/CRISPR analysis: Daudi cells with stable Cas9 expression were derived as previously described. ${ }^{50}$ Briefly, Daudi cells with stable Streptococcus pyogenes Cas9 expression were established by infection with lentiviral transduction and blasticidin selection, using pLentiCas9-Blast (Addgene plasmid \#52962). Cas9 activity was validated by transduction of the Daudi Cas9+ cells with a test lentivirus, which encodes a GFP and a sgRNA that targets GFP. ${ }^{51}$ The PXPR-011 plasmid (provided by John Doench, Broad Institute, Cambridge, MA, USA) was used to construct this test virus. Cas9 activity was evident in $>85 \%$ of the selected Daudi cells by flow cytometry analysis (the residual $15 \%$ of cells that continue to express GFP may be cells where the non-homologous end-joining pathway correctly repaired the Cas9induced DNA double-strand break). ${ }^{51}$ To obtain NF-KB subunit knockdown by CRISPR/Cas9 genome editing, the following sgRNAs were designed using CRISPRdirect (http://crispr.dbcls.jp/): ${ }^{2}$ RelA 5'-AGTCCTTTCCTACAAGCTCG-3' and 5'-AGCTGATGTGCACCGACAAG-3'; RelB 5'-GGTCTGGCGACGCGGCGACT-3' and 5'-AGCGGCCCTCGCACTCGTAG-3'; c-Rel 5'-AAATGTGAAGGGCGATCAGC-3' and 5'-ATTGGGTTCGAGACA ACAGG-3; p52 5'-TAGGCTGTTCCACGATCACC-3'. Oligonucleotides were synthesized by Life Technologies (Paisley, UK), were individually cloned into the lentiGuide-Puro vector (Addgene plasmid \#52963), according to the protocol from the Zhang laboratory (http://genomeengineering.org/), ${ }^{53}$ and were sequence verified. VSV-G pseudotyped lentiviruses encoding a sgRNA were produced in $293 \mathrm{~T}$ cells and used to transduce Daudi Cas9+ cells. Cells transduced with sgRNA-encoding lentivirus were selected by puromycin. (d-g) Treatment of the Daudi Burkitt's lymphoma cell line with the IкB kinase inhibitors BMS 345541 and TPCA-1 reduces BACH2 mRNA and protein levels. Daudi cells were treated with either $5 \mu$ M BMS 345541 (Calbiochem, San Diego, CA, USA) or $10 \mu \mathrm{M}$ TPCA-1 (Calbiochem) for the times shown. RNA or protein was extracted for either q-PCR $(\mathbf{d}, \mathbf{f})$ or western blot $(\mathbf{e}, \mathbf{g})$ analysis using the Bach2 antibody, ABN171 (Merck Millipore). (h, i) Treatment of the BL41 Burkitt's lymphoma cell lines with the IкB kinase inhibitor TPCA-1 reduces BACH2 mRNA and protein levels. BL41 cells were treated with $10 \mu \mathrm{M}$ TPCA-1 for the times shown. RNA or protein was extracted for either q-PCR (h) or western blot (i) analysis. q-PCR data represent the mean of three independent experiments \pm s.e.m., ${ }^{*} P<0.05$, ${ }^{* *} P<0.01$, ${ }^{* * *} P<0.001$, ${ }^{* * * *} P<0.0001$ (unpaired Student's $t$-test). Daudi and BL41 cells were obtained from the American Type Culture Collection (Teddington, UK) and grown in RPMI-1640 medium (Lonza, Basel, Switzerland; supplemented with 10\% (v/v) fetal bovine serum (Invitrogen, Paisley, UK) and 2 mm L-glutamine (Lonza)). Cell lines were sent to LGC Standards for authentication by short tandem repeat profiling.

previous studies of the role of c-Rel in lymphoma have used either patient cells or established laboratory cell lines. In both cases, by analysing 'end-stage' cancer cells, these investigations will have focused on the antiapoptotic effects of NF-KB, which we also see, but will have missed any more complex roles that might occur during the process of lymphomagenesis itself. Our study has therefore allowed the description of a previously unknown role for c-Rel in the prevention of B-cell lymphoma development by regulating the expression of Bach2. However, NF-KB regulation of Bach2 is not restricted to $c$-Rel and our data also support a role for RelA. Interestingly, in E $\mu$-Myc mice RelA regulation of Bach2 was only seen in the 'end-stage' lymphomas (Figures $3 \mathrm{~h}$ and i), suggesting that c-Rel is the primary driver of Bach2 expression. Nonetheless, this demonstrates the complex interplay between NF$\mathrm{KB}$ subunits, as well as the potential for stage-specific regulation of gene expression during lymphomagenesis. It will be of interest to see if c-Rel can also contribute to the regulation of NF-KBdependent senescence reported in $\mathrm{E} \mu$-Myc lymphoma cells. ${ }^{27,28}$

Bach2 is a transcription factor and known as B-cell tumour suppressor. Interestingly, a recent report illustrated that Bach2 is required for c-Myc-dependent induction of p53 in pre-B cells. ${ }^{39}$ Moreover, loss of Bach2 is associated with the development of pre-B acute lymphoblastic leukaemia. ${ }^{39}$ Bach2 promoter activity is also reduced upon BCR-ABL expression in chronic myeloid leukaemia, through regulation by the transcription factor, Pax5, suggesting that suppression of Bach2 may contribute to lymphoid blast crisis in chronic myeloid leukaemia. ${ }^{44}$ Although we cannot rule out contributions from the other c-Rel-regulated genes we identified, we propose that induction of Bach2 expression by c-Rel/NF-KB provides one mechanism that allows these factors to function as tumour suppressors in the early stages of B-cell lymphoma development. However, some reports have suggested that Bach2 may also contribute towards malignancy in some contexts. ${ }^{45}$ Since the tumour suppressor functions of Bach2 are associated with p53, it is possible that p53 loss or mutation is also the trigger for a change in Bach2 function. Therefore, the consequences of NF-KB regulation of
Bach2 expression may vary depending on the stage of lymphoma development.

\section{Accession numbers}

NF-kB ChIP-Seq data sets have been published ${ }^{41}$ (gene expression omnibus, accession code GSE55105).

Microarray data have been submitted to ArrayExpress, accession code E-MTAB-2774.

\section{CONFLICT OF INTEREST}

The authors declare no conflict of interest.

\section{ACKNOWLEDGEMENTS}

We thank Fiona Oakley, Sonia Rocha, Derek Mann, Claire Richardson, Saimir Luli, Elaine Willmore and all members of the NDP laboratory for their helpful advice and assistance. We are very grateful to Michael J. Walsh for assistance with generation of CRISPR/Cas9 knock-out cell lines. JEH is funded by Leukemia Lymphoma Research grant 11022, JAB and HS are funded by the Wellcome Trust grant 094409, further funding from the NDP lab was obtained from Cancer Research UK grant C1443/ A12750. The IVIS Spectrum was funded by Welcome Trust Equipment grant 087961. BZ and BEG are funded by US National Institutes of Health (grants K08 CA140780 and RO1 CA12850) and by a Burroughs Wellcome Medical Scientist career award.

\section{AUTHOR CONTRIBUTIONS}

JEH performed the majority of the experimental work and contributed to concept and design of experiments and manuscript writing. JAB and $\mathrm{HS}$ assisted with procedures involving $\mathrm{E} \mu-\mathrm{Myc}$ mice. BZ performed ChIP-Seq analysis. KJC provided advice on working with $\mathrm{E} \mu-\mathrm{Myc}$ mice and assisted with data analysis. HDT provided training and assisted with lymphoma reimplantation studies. CB provided advice on B-cell lymphoma and contributed to experimental concepts and design. SJC performed bioinformatics analysis of microarray data. BEG performed analysis of ChIP-Seq data and contributed to experimental concepts and design. NDP contributed to concept and design of experiments and manuscript writing. 


\section{REFERENCES}

1 Perkins ND. The diverse and complex roles of NF-KB subunits in cancer. Nat Rev Cancer 2012; 12: 121-132.

2 Staudt LM. Oncogenic activation of NF-KB. Cold Spring Harb Perspect Biol 2010; 2: a000109.

3 Davis RE, Brown KD, Siebenlist U, Staudt LM. Constitutive nuclear factor KB activity is required for survival of activated B cell-like diffuse large B cell lymphoma cells. J Exp Med 2001; 194: 1861-1874.

4 Feuerhake F, Kutok JL, Monti S, Chen W, LaCasce AS, Cattoretti G et al. NFkB activity, function, and target-gene signatures in primary mediastinal large B-cell lymphoma and diffuse large B-cell lymphoma subtypes. Blood 2005; 106: 1392-1399.

5 Rosenwald A, Wright G, Leroy K, Yu X, Gaulard P, Gascoyne RD et al. Molecular diagnosis of primary mediastinal $B$ cell lymphoma identifies a clinically favorable subgroup of diffuse large B cell lymphoma related to Hodgkin lymphoma. J Exp Med 2003; 198: 851-862.

6 Kuppers R. The biology of Hodgkin's lymphoma. Nat Rev Cancer 2009; 9: 15-27.

7 Perkins ND. Integrating cell-signalling pathways with NF-KB and IKK function. Nat Rev Mol Cell Biol 2007; 8: 49-62.

8 Gilmore TD. Multiple mutations contribute to the oncogenicity of the retroviral oncoprotein v-Rel. Oncogene 1999; 18: 6925-6937.

9 Fullard N, Wilson CL, Oakley F. Roles of c-Rel signalling in inflammation and disease. Int J Biochem Cell Biol 2012; 44: 851-860.

10 Courtois G, Gilmore TD. Mutations in the NF-KB signaling pathway: implications for human disease. Oncogene 2006; 25: 6831-6843.

11 Grumont RJ, Gerondakis S. The subunit composition of NF-KB complexes changes during B-cell development. Cell Growth Differ 1994; 5: 1321-1331.

12 Liou HC, Sha WC, Scott ML, Baltimore D. Sequential induction of NF-kB/Rel family proteins during B-cell terminal differentiation. Mol Cell Biol 1994; 14: 5349-5359.

13 Weih F, Carrasco D, Bravo R. Constitutive and inducible Rel/NF-KB activities in mouse thymus and spleen. Oncogene 1994; 9: 3289-3297.

14 Kontgen F, Grumont RJ, Strasser A, Metcalf D, Li R, Tarlinton D et al. Mice lacking the c-rel proto-oncogene exhibit defects in lymphocyte proliferation, humoral immunity, and interleukin-2 expression. Genes Dev 1995; 9: 1965-1977.

15 Tumang JR, Hsia CY, Tian W, Bromberg JF, Liou HC. IL-6 rescues the hyporesponsiveness of $\mathrm{c}-$ Rel deficient $\mathrm{B}$ cells independent of $\mathrm{BCl}-\mathrm{xL}, \mathrm{Mcl}-1$, and $\mathrm{BCl}-2$. Cell Immunol 2002; 217: 47-57.

16 Tumang JR, Owyang A, Andjelic S, Jin Z, Hardy RR, Liou ML et al. c-Rel is essential for B lymphocyte survival and cell cycle progression. Eur J Immunol 1998; 28: 4299-4312.

17 Cariappa A, Liou HC, Horwitz BH, Pillai S. Nuclear Factor KB is required for the development of marginal zone B lymphocytes. J Exp Med 2000; 192: 1175-1182.

18 Starczynowski DT, Reynolds JG, Gilmore TD. Deletion of either C-terminal transactivation subdomain enhances the in vitro transforming activity of human transcription factor REL in chicken spleen cells. Oncogene 2003; 22: 6928-6936.

19 Chin M, Herscovitch M, Zhang N, Waxman DJ, Gilmore TD. Overexpression of an activated REL mutant enhances the transformed state of the human B-lymphoma BJAB cell line and alters its gene expression profile. Oncogene 2009; 28: 2100-2111.

20 Fan $Y$, Rayet B, Gelinas C. Divergent C-terminal transactivation domains of Rel/NF-KB proteins are critical determinants of their oncogenic potential in lymphocytes. Oncogene 2004; 23: 1030-1042.

21 Barth TF, Martin-Subero Jl, Joos S, Menz CK, Hasel C, Mechtersheimer G et al. Gains of $2 p$ involving the REL locus correlate with nuclear c-Rel protein accumulation in neoplastic cells of classical Hodgkin lymphoma. Blood 2003; 101: 3681-3686.

22 Joos S, Menz CK, Wrobel G, Siebert R, Gesk S, Ohl S et al. Classical Hodgkin lymphoma is characterized by recurrent copy number gains of the short arm of chromosome 2. Blood 2002; 99: 1381-1387.

23 Martin-Subero Jl, Gesk S, Harder L, Sonoki T, Tucker PW, Schlegelberger B et al. Recurrent involvement of the REL and BCL11A loci in classical Hodgkin lymphoma. Blood 2002; 99: 1474-1477.

24 Lenz G, Davis RE, Ngo VN, Lam L, George TC, Wright GW et al. Oncogenic CARD11 mutations in human diffuse large B cell lymphoma. Science 2008; 319: 1676-1679.

25 Enciso-Mora V, Broderick P, Ma Y, Jarrett RF, Hjalgrim H, Hemminki K et al. A genomewide association study of Hodgkin's lymphoma identifies new susceptibility loci at 2p16.1 (REL), 8q24.21 and 10p14 (GATA3). Nat Genet 2010; 42: 1126-1130.

26 Curry CV, Ewton AA, Olsen RJ, Logan BR, Preti HA, Liu YC et al. Prognostic impact of C-REL expression in diffuse large B-cell lymphoma. J Hematop 2009; 2: 20-26.

27 Chien Y, Scuoppo C, Wang X, Fang X, Balgley B, Bolden JE et al. Control of the senescence-associated secretory phenotype by NF-KB promotes senescence and enhances chemosensitivity. Genes Dev 2011; 25: 2125-2136.

28 Jing H, Kase J, Dorr JR, Milanovic M, Lenze D, Grau M et al. Opposing roles of NF-KB in anti-cancer treatment outcome unveiled by cross-species investigations. Genes Dev 2011; 25: 2137-2146.

29 Keller U, Huber J, Nilsson JA, Fallahi M, Hall MA, Peschel C et al. Myc suppression of Nfkb2 accelerates lymphomagenesis. BMC cancer 2010; 10: 348.

30 Keller U, Nilsson JA, Maclean KH, Old JB, Cleveland JL. Nfkb 1 is dispensable for Myc-induced lymphomagenesis. Oncogene 2005; 24: 6231-6240.
31 Carlsen H, Moskaug JO, Fromm SH, Blomhoff R. In vivo imaging of NF-kB activity. J Immunol 2002; 168: 1441-1446.

32 Harris AW, Pinkert CA, Crawford M, Langdon WY, Brinster RL, Adams JM. The $E$ mu-myc transgenic mouse. A model for high-incidence spontaneous lymphoma and leukemia of early B cells. J Exp Med 1988; 167: 353-371.

33 Hoyer KK, French SW, Turner DE, Nguyen MT, Renard M, Malone CS et al. Dysregulated TCL1 promotes multiple classes of mature B cell lymphoma. Proc Natl Acad Sci USA 2002; 99: 14392-14397.

34 Fan Y, Dutta J, Gupta N, Fan G, Gelinas C. Regulation of programmed cell death by $\mathrm{NF}-\mathrm{KB}$ and its role in tumorigenesis and therapy. Adv Exp Med Biol 2008; 615: 223-250.

35 Eischen CM, Weber JD, Roussel MF, Sherr CJ, Cleveland JL. Disruption of the ARF-Mdm2-p53 tumor suppressor pathway in Myc-induced lymphomagenesis. Genes Dev 1999; 13: 2658-2669.

36 Sasaki S, Ito E, Toki T, Maekawa T, Kanezaki R, Umenai T et al. Cloning and expression of human B cell-specific transcription factor $\mathrm{BACH} 2$ mapped to chromosome 6q15. Oncogene 2000; 19: 3739-3749.

37 Muto A, Tashiro S, Tsuchiya H, Kume A, Kanno M, Ito E et al. Activation of Maf/AP-1 repressor Bach2 by oxidative stress promotes apoptosis and its interaction with promyelocytic leukemia nuclear bodies. J Biol Chem 2002; 277: 20724-20733.

38 Hoshino H, Kobayashi A, Yoshida M, Kudo N, Oyake T, Motohashi H et al. Oxidative stress abolishes leptomycin B-sensitive nuclear export of transcription repressor Bach2 that counteracts activation of Maf recognition element. J Biol Chem 2000; 275: 15370-15376.

39 Swaminathan S, Huang C, Geng H, Chen Z, Harvey R, Kang H et al. BACH2 mediates negative selection and p53-dependent tumor suppression at the pre-B cell receptor checkpoint. Nat Med 2013; 19: 1014-1022.

40 Msaki A, Sanchez AM, Koh LF, Barre B, Rocha S, Perkins ND et al. The role of RelA (p65) threonine 505 phosphorylation in the regulation of cell growth, survival, and migration. Mol Biol Cell 2011; 22: 3032-3040.

41 Zhao B, Barrera LA, Ersing I, Willox B, Schmidt SC, Greenfeld H et al. The NF-kB genomic landscape in lymphoblastoid B cells. Cell Rep 2014; 8: 1595-1606.

42 Grossmann M, Metcalf D, Merryfull J, Beg A, Baltimore D, Gerondakis S. The combined absence of the transcription factors Rel and RelA leads to multiple hemopoietic cell defects. Proc Natl Acad Sci USA 1999; 96: 11848-11853.

43 Pham LV, Tamayo AT, Yoshimura LC, Lin-Lee YC, Ford RJ. Constitutive NF-KB and NFAT activation in aggressive B-cell lymphomas synergistically activates the CD154 gene and maintains lymphoma cell survival. Blood 2005; 106: 3940-3947.

44 Casolari DA, Makri M, Yoshida C, Muto A, Igarashi K, Melo JV. Transcriptional suppression of $\mathrm{BACH} 2$ by the Bcr-Abl oncoprotein is mediated by PAX5. Leukemia 2013; 27: 409-415.

45 Ichikawa S, Fukuhara N, Katsushima H, Takahashi T, Yamamoto J, Yokoyama H et al. Association between $\mathrm{BACH} 2$ expression and clinical prognosis in diffuse large B-cell lymphoma. Cancer Sci 2014; 105: 437-444.

46 Du P, Kibbe WA, Lin SM. lumi: a pipeline for processing Illumina microarray. Bioinformatics 2008; 24: 1547-1548.

47 Gentleman RC, Carey VJ, Bates DM, Bolstad B, Dettling M, Dudoit S et al. Bioconductor: open software development for computational biology and bioinformatics. Genome Biol 2004; 5: R80.

48 Smyth GK. limma: linear models for microarray data. In: Gentleman RC, Carey VJ, Dudoit S, Irizarry R, Huber W (eds). Bioinformatics and Computational Biology Solutions Using R and Bioconductor. Springer: New York, 2005, pp 397-420.

49 Pfaffl MW. A new mathematical model for relative quantification in real-time RT-PCR. Nucleic Acids Res 2001; 29: e45.

50 Greenfeld H, Takasaki K, Walsh MJ, Ersing I, Bernhardt K, Ma Y et al. TRAF1 coordinates polyubiquitin signaling to enhance Epstein-Barr virus LMP1mediated growth and survival pathway activation. PLoS Pathog 2015; 11: e1004890.

51 Doench JG, Hartenian E, Graham DB, Tothova Z, Hegde M, Smith I et al. Rational design of highly active sgRNAs for CRISPR-Cas9-mediated gene inactivation. Nat Biotechnol 2014; 32: 1262-1267.

52 Naito Y, Hino K, Bono H, Ui-Tei K. CRISPRdirect: software for designing CRISPR/Cas guide RNA with reduced off-target sites. Bioinformatics 2015; 31: 1120-1123.

53 Sanjana NE, Shalem O, Zhang F. Improved vectors and genome-wide libraries for CRISPR screening. Nat Methods 2014; 11: 783-784.

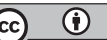

This work is licensed under a Creative Commons Attribution 4.0 International License. The images or other third party material in this article are included in the article's Creative Commons license, unless indicated otherwise in the credit line; if the material is not included under the Creative Commons license, users will need to obtain permission from the license holder to reproduce the material. To view a copy of this license, visit http://creativecommons.org/licenses/ by/4.0/ 